\title{
Strafudmåling i miljøstraffesager i Danmark
}

\author{
Af Gorm Toftegaard Nielsen ${ }^{1}$
}

Denmark adopted its first Law on the protection of the environment, with its own rule on sentencing, in 1973. This rule has since been developed through a number of amendments to the Law, with the aim of imposing stricter punishment. Prosecutions are typically brought against commercial undertakings, and these have concerned heavier fines either by reference to the harm done to the environment or to the undertaking's profits from infringing the Law. In many cases local environmental authorities have been reluctant to enforce the Law strictly against local undertakings, and the authorities have found it difficult to calculate the profits derived from infringements. The author's study in 1995 showed a significantly higher level of punishment than his corresponding study in 2005. After the latter study, in 2008 there was an amendment to the Law and the Director of Public Prosecutions has issued guidelines considerably increasing the demands for punishment to be made by prosecuting authorities. This initiative appears to have had an effect, though there have been, as yet, few reported cases.

Den første miljøbeskyttelseslov i Danmark er fra 1973. Miljøbeskyttelsesloven i Danmark regulerer ikke hele naturbeskyttelsen, men kun forureningsspørgsmål. 1973-lovens straffebestemmelse var ret enkel, idet den bestemte, at overtrædelser af loven, regler udstedt i medfør af loven eller afgørelser truffet efter loven »straffes med bøde, hæfte eller fængsel indtil 1 år«. Bestemmelsen indeholdt desuden en regel om, at også juridiske personer kunne straffes for overtrædelse af loven.

I den nugældende miljøbeskyttelseslov er sket en betydelig udvikling af straffebestemmelsen:

» 110. Medmindre højere straf er forskyldt efter den øvrige lovgivning straffes med bøde den, der overtræder ...

Stk. 2. Straffen kan stige til fængsel i indtil 2 år, hvis overtrædelsen er begået forsætligt eller ved grov uagtsomhed, og hvis der ved overtrædelsen er

1) voldt skade på miljøet eller fremkaldt fare derfor eller

* Title in English: The quantum of sentences in criminal environmental prosecutions in Denmark. Original in Danish. 
2) opnået eller tilsigtet en økonomisk fordel for den pågældende selv eller andre, herunder ved besparelser

Stk. 4. Der kan pålægges selskaber m.v. (juridiske personer) strafansvar efter reglerne i straffelovens 5. kapitel.

Stk. 5. Ved udmåling af bødestraf skal der lægges vægt på de hensyn, der er nævnt i $§ 1{ }^{2}$

Det er en skærpende omstændighed, hvis overtrædelsen er begået i forbindelse med udøvelse af erhverv.

Stk. 6. Er der ved en overtrædelse opnået en økonomisk fordel, konfiskeres denne efter reglerne i straffelovens 9. kapitel, selv om der ved overtrædelsen ikke er voldt skade på miljøet eller er fremkaldt fare derfor. Kan der ikke ske konfiskation, skal der tages særskilt hensyn hertil ved udmåling af en bøde, herunder en tillægsbøde.«

Denne bestemmelse er blevet modellen for andre love inden for miljøsagerne $\mathrm{i}$ bred forstand, f.eks. naturbeskyttelseslovens $\S 89$ og byggefredningslovens $\S 34$.

\section{Forholdet til straffelovens principper}

Modellen kan siges at være en overførsel af den almindelige straffelovs principper for strafudmålingen. I Danmark gælder straffelovens almindelige regler efter $\S 2$ også for straffesager efter speciallove som f.eks. miljøbeskyttelsesloven. Efter straffelovens $\S 80$ skal straffen fastsættes under hensyntagen til ensartethed i retsanvendelsen og således, at der lægges vægt på lovovertrædelsens grovhed og på oplysninger om gerningsmanden. Grovheden afhænger af »den med lovovertrædelsen forbundne skade, fare og krænkelse samt til, hvad gerningsmanden indså eller burde have indset herom«. Ved vurderingen af gerningsmanden skal der »tages hensyn til dennes almindelige personlige og sociale forhold, dennes forhold før og efter gerningen samt dennes bevæggrunde til gerningen.«

Bestemmelsen om miljøovertrædelsernes grovhed svarer i meget høj grad til straffelovens bestemmelse om forbrydelsens grovhed. Det afgørende er skaden og den subjektive skyld. Men det er åbenbart, at lovgiver i miljøbeskyttelsesloven lægger meget stor vægt på spørgsmålet, om overtrædelsen er båret af et økonomisk motiv, og om der er opnået et udbytte, jf. § 110, stk. 6 .

Straffen i stort set alle miljøstraffesager i Danmark er en bøde. Det er derfor væsentlig, at også straffelovens $\S 51$, stk. 3, indeholder en særlig regel om, at der skal tages »særligt hensyn til den skyldiges betalingsevne og til den opnåede eller tilsigtede fortjeneste eller besparelse."

På et punkt adskiller praksis på miljøområdet sig markant fra den almindelige strafferet. Det er meget få bøder på miljøområdet, hvor den dømtes indtægtsforhold er tillagt nogen betydning. Ved straffelovsovertrædelser er udgangspunktet 
efter § 51, stk. 1, at bøder idømmes i form af dagbøder, således at størrelsen af de enkelte dagbøder afspejler den dømtes indtægtsforhold og antallet af dagbøder overtrædelsens grovhed. Dog anføres i stk. 2, at der i stedet kan idømmes en sumbøde, hvis dagbøder vil medføre et for lavt beløb i forhold til, at den dømte har opnået eller tilsigtet at opnå en betydelig økonomisk gevinst ved overtrædelsen.

Dagbødesystemet har aldrig været populært hos danske praktikere. Det hænger til dels sammen med, at næsten alle bødesager afgøres ved, at den skyldige vedtager et af politiet udfærdiget bødeforlæg, og disse bødeforlæg lyder på et bestemt beløb og altså ikke dagbøder. Kun hvis den tiltalte ikke vil vedtage bødeforlægget, går sagen i retten. Når dommeren får sagen, er den f.eks. tilbudt afgjort med en bøde på $1800 \mathrm{kr}$., fordi den tiltalte har lavet et butikstyveri til $900 \mathrm{kr}$. Hvis dommeren er enig med anklagemyndigheden, skal tiltalte idømmes dagbøder. I praksis regner dommeren baglæns og fastsætter antallet af bøder til f.eks. 6, hvorefter hver dagbøde bliver 300 kr., uden at nogen drøfter tiltaltes indtægt. Kun hvis der er tale om særligt lavtlønnede, tages der hensyn hertil. Det danske system kan naturligvis ændres, så også bødeforlæg udstedes som dagbøder, men der er blandt praktikere ingen interesse i en sådan ændring, som opfattes som unødigt bureaukratisk. Bøder i spiritussager, som typisk er betydeligt højere end straffelovsbøder, fastsættes ved at gange den tiltaltes nettomånedsløn med alkoholpromillen. ${ }^{3}$

Der er således intet til hinder for, at domstolene ved fastsættelsen af bøder for overtrædelse af miljølovgivningen tager hensyn til den tiltaltes indtægtsforhold eller omsætning. Systemet er velkendt bl.a. fra EU's kartelbøder, hvor omsætningen spiller en betydelig rolle. I danske miljøsager anføres meget sjældent noget om tiltaltes indtægts- eller formueforhold. Det hænger nok sammen med, at den væsentligste faktor ved bødeudmålingen er den opnåede eller tilsigtede fortjeneste. Når bøden udregnes ud fra denne faktor, er der ikke rigtig plads til at tage hensyn til den dømtes indtægtsforhold. Denne faktors betydning medfører også en fravigelse af det almindelige princip i straffelovens $\S 81, \mathrm{nr}$. 2 om, at det er skærpende, hvis en forbrydelse udføres af flere i forening. Hvis A og B sammen har drevet et dambrug ulovligt, deles bøden mellem dem, da den udregnes som en brøk af fortjenesten. Den bøde, der deles, er den bøde A ville have fået, hvis han selv havde drevet virksomheden.

Det bør til sidst nævnes, at den vel mest anvendte udmålingsregel i straffeloven er $\S 81 \mathrm{nr} .1 \mathrm{om}$, at det normalt skal indgå som en skærpende omstændighed, at tiltalte tidligere er straffet af betydning for sagen, naturligvis også anvendes i miljøstraffesager. 


\section{Udviklingen af retspraksis}

Da den første miljøbeskyttelseslov blev vedtaget i 1973, var opfattelsen nok nærmest, at speciallovsovertrædelser eller forvaltningsstraffesager ikke var rigtige straffesager, men handlede om at få gennemtvunget en lovliggørelse. Retsplejelovens $\S 684$, stk. 1 , nr. 1 bestemte - og bestemmer stadig - efter norsk forbillede, at sager, der handler om at gennemtvinge pligter over for det offentlige ifølge love om politivæsnet, bygningsvæsnet, landbovæsnet, skattevæsnet og lignende love, behandles efter reglerne om straffesager, også i de tilfælde, hvor der ikke var nogen påstand om straf, men alene om fysisk lovliggørelse. Kort sagt medfører reglen, at hvis fredningsmyndighederne ønsker et ulovligt opdyrket område ført tilbage til den tidligere tilstand, rejses der en straffesag af anklagemyndigheden, og her påstår anklagemyndigheden den tiltalte idømt tvangsbøder for at tvinge ham til inden en vis frist at retablere den tidligere tilstand. Der blev i disse sager tidligere ofret meget store resurser på den forvaltningsretlige lovliggørelse og for et syns skyld blev også idømt en bøde, ofte på 500 kr. Opfattelsen var for næsten alle sager om overtrædelse af forvaltningslovgivningen, at straffen var underordnet. Det væsentlige var lovliggørelsen af den fysiske tilstand. Der var vel kun tre væsentlige undtagelser. Skattestraffesagerne og sagerne om ulovligt fiskeri var de eneste områder, hvor straffene var rimeligt hårde og lignede sanktionerne for straffelovsovertrædelser. Arbejdsmiljøsagerne blev ikke afgjort med bøder på få hundrede kroner, men med bøder på få tusinde kroner. Det var og er karakteristisk for disse tre områder, at de alle blev håndhævet af statslige myndigheder, og at begge havde et kontor, som særligt beskæftigede sig med sanktioneringen af overtrædelser.

\section{Kommunal håndhævelse}

Tilsynet med miljølovgivningens overholdelse blev overladt til kommunale myndigheder, der som bekendt styres af lokalpolitikere. I miljøministeriet blev oprettet en særlig miljøstyrelse, som havde et tilsynskontor, der netop overvågede de lokale tilsynsmyndigheders indsats. Chefen for dette kontor Mogens Moe havde en licentiatafhandling (svarer til ph.d.) om de sager, hvor forvaltningsmyndighederne pålagde borgerne bøder. Der var altså tale om en person med en strafferetlig kunnen på et betydeligt højere niveau end hos nogen tilsvarende forvaltningsmyndighed. Også andre af miljøstyrelsens jurister havde en meget høj faglig kompetence. Miljøjuraen var på mange måder et højprofileret fag, som tiltrak også jurister fra eliten. Netop kombinationen af en fagligt dygtig og engageret statslig myndighed og et kommunalt tilsyn fik afgørende betydning for udviklingen af miljøstrafferetten. 
Miljøstyrelsen opfattede med rette, at en af de væsentligste landevindinger ved den nye lov var, at en lang række virksomheder, som var opført på en særlig liste, kun måtte etablere sig eller foretage udvidelser, hvis de forinden havde opnået miljømyndighedernes godkendelse. En meget stor virksomhed Superfos (omsætning ca. 750 mio. kr.) opførte en stor ammoniaktank uden forinden at søge den fornødne miljøgodkendelse. Miljøstyrelsen opfattede forholdet som en klar og meget grov overtrædelse af loven og anmeldte virksomheden til politiet. Styrelsen meldte ud til offentligheden, at man fandt en bøde på $100.000 \mathrm{kr}$. passende. Sagen fik en betydelig pressedækning, da håndhævelse af miljølovgivningen på dette tidspunkt politisk var et rimeligt højt profileret emne. Både byretten og Vestre Landsret den 19.4.1979 lod sagen afgøre med en bøde på $10.000 \mathrm{kr}$. Den lave bøde skyldtes for det første, at domstolene betragtede opførelsen uden godkendelse som en formel overtrædelse af ringe strafværdighed, da det viste sig, at den opførte tank stort set svarede til den senere godkendte tank. Det andet forhold, som bevirkede, at bøden blev lav, var, at kommunen havde givet byggetilladelse til opførelsen af tanken, og at amtet som den miljømæssig kompetente myndighed også var klar over opførelsen, uden at det havde reageret. Der er ingen tvivl om, at Mogens Moe har ret, når han skriver, at udviklingen i strafudmålingen længe var præget af den uheldige start med Superfos-sagen og at den set »med domstolenes øjne demonstrerede ..., at miljømyndighederne selv var efterladende, og at de var hysteriske i deres bødekrav. Det lave niveau, som blev lagt i starten, har været med til at holde igen på bøderne, fordi domstolene - uanset mellemkommende lovændringer - lægger vægt på hidtidig praksis. $\ll^{4}$

Mogens Moe bemærker samme sted, at fredningsstyrelsen, som bl.a. stod for håndhævelsen af reglerne om beskyttelse af udryddelsestruede dyr, i begyndelsen af firserne demonstrerede, at det kunne lade sig gøre at forklare anklagemyndighed og domstole strafværdigheden af overtrædelserne. Han nævner en sag, ${ }^{5}$ hvor en dyrehandler fik en bøde på 100.000 kr. og konfiskation af 17 leopardskind og 1 gepardskind.

Det er næppe rigtigt, at forskellen primært skyldes myndighedernes forskellige håndtering af sagerne. Retsvæsnets uvilje mod Superfos-sagen skyldtes primært, at der ikke var sket nogen forurening, og at der var tale om en samfundsgavnlig produktion, som de ansvarlige politikere fandt noget mere væsentlig end den formelle overtrædelse. Omvendt er udryddelsen af de nævnte dyr klart strafværdig selv for en barnesjæl. Dommene kan således i en vis forstand hævdes meget klart at demonstrere, hvorfor det er så vanskeligt at bestemme de forskellige overtrædelsers strafværdighed. Det fik derfor begrænset eller ingen betydning, at rigsadvokaten den 9.10.1979 udsendte en meddelelse til anklagerne om, at de 
skulle søge gennemført en skærpelse af straffene i miljøsager, således at bødepåstanden blev afpasset efter overtrædelsens grovhed. I samme meddelelse blev anført, at bøden, hvis der ved overtrædelsen var opnået eller tilsigtet en fortjeneste, skulle fastsættes under hensyn hertil.

Den næste større sag vedrørte et tekstiltrykkeri med en omsætning på ca. 100 mio. kr. Virksomhedens udledning havde ødelagt det kommunale kloaksystem, og kommunen havde måttet etablere et nyt. For at undgå at få dette ødelagt gav kommunen virksomheden et påbud om at etablere et nyt rensningsanlæg inden en vis frist. Virksomheden etablerede først anlægget 5 måneder efter fristens udløb. Virksomheden blev efter kommunens anmeldelse tiltalt for denne overtrædelse. Anklagemyndigheden påstod en bøde på $35.000 \mathrm{kr}$. og konfiskation af $34.871 \mathrm{kr}$. Da det efter både anklagemyndighedens og kommunens opfattelse var udsigtsløst at forsøge at få domstolene til at vurdere overtrædelsen som grov nok til at bære en rimelig bøde, forsøgte man at udregne virksomhedens fortjeneste ved overtrædelsen. Besparelsen var 5 måneders forrentning og afskrivning af anlægsudgifterne og 5 måneders driftsudgifter. De sidste var små, men på grund af et ekstremt højt renteniveau udgjorde rentebesparelsen ca. $30.000 \mathrm{kr}$., og det samlede beløb var derfor opgjort til $34.871 \mathrm{kr}$. Bødepåstanden var udregnet ved at se på, hvad en virksomhed skulle betale i bøde, hvis den blev dømt for 5 måneders for sen indbetaling af indeholdt kildeskat på $34.871 \mathrm{kr}$. Bøden ville i kildeskattesagen være blevet 35.000. Anklagerens argumentation var, at hvis en virksomhed ønskede at spare ved at udskyde en betaling, måtte det ikke være billigere at udskyde udgifter til miljøet end til skattevæsnet. Problemet var, at hverken anklagemyndighed eller kommune havde erfaring med den slags beregninger, og man havde overset, at virksomhedens besparelse var langt mindre, fordi den største del af renterne dækkede over inflation, således at udskydelsen havde bevirket, at anlægget var blevet betydeligt dyrere pga. prisforhøjelser. Virksomheden oplyste, at fortjenesten alene var 9.-10.000 kr., og landsretten idømte en bøde på 10.000 kr. De fleste opfattede forholdet sådan, at det ikke havde kostet virksomheden en krone at overtræde loven. Dette er ikke ganske rigtigt, da de sparede $10.000 \mathrm{kr}$. skattemæssigt er et bruttobeløb og derfor efter skattebesparelsen måske alene var 5.000 kr., mens bøden ikke er fradragsberettiget. Reelt har overtrædelsen kostet virksomheden $10.000 \mathrm{kr}$. minus $5.000 \mathrm{kr}^{6}{ }^{6}$

I marts 1983 udarbejdede miljøstyrelsen et notat om de større miljøstraffesager i 1979-1982. ${ }^{7}$ Materialet omfatter 7 landsretsdomme. I en af sagerne blev idømt en bøde på størrelse med anklagemyndighedens påstand, men det generelle indtryk er, at bøderne var betydeligt lavere end påstået og $\mathrm{i}$ adskillige tilfælde på 10 \% af påstanden. I sine kommentarer anfører styrelsen, at bødeudmålingen ofte 
er præget af tilsynsmyndighedernes manglende reaktion på overtrædelser, at miljømyndighedernes og anklagemyndighedens beregninger af fortjenester ofte tilsidesættes, og at det oftest ikke lykkes at forklare domstolene om skaderne på miljøet eller risikoen for disse. Hvad embedsmændene ikke skriver er, at det i betragtning af den offentlige interesse for emnet er påfaldende, at rigsadvokaten ikke forsøgte at appellere nogen af afgørelserne til Højesteret. Jeg tror ikke, det er forkert at antage, at rigsadvokatens interesse for dette område var begrænset. For egen regning kan det oplyses, at der hos mange dommere var megen skepsis over for biologerne, som ofte blev betragtet som venstrefløjens rester fra studenteroprøret, som forsøgte at bekæmpe den industri, der dybest set skulle redde landets økonomi. Det var også meget tydeligt, at mange kommuner søgte at vise en vis erhvervsvenlighed. Underforstået her forfulgte man ikke erhvervslivet.

\section{To betaenkninger}

I 1983 afgav et udvalg betænkning nr. 981.1983 om håndhævelse af bygge- og miljølovgivningen. Det blev i betænkningen s. 15 klart markeret, at det ikke var muligt at opnå en bedre håndhævelse, hvis der ikke var politisk vilje til at sikre lovens overholdelse. Det er også karakteristisk for betænkningen, at flertallet finder domstolenes strafudmåling særdeles mild, men at justitsministeriets enlige repræsentant i udvalget ikke tilslutter sig denne kritik.

Kort efter offentliggørelsen af håndhævelsesbetænkningen afgav et andet udvalg (hvor der dog også var medlemmer, der optrådte $\mathrm{i}$ håndhævelsesudvalget) betænkning nr. 996.1983 om ansvarsplacering og reaktionsmuligheder i kommunestyret. Udvalget foreslog en bestemmelse om, at kommunalbestyrelsesmedlemmer kunne straffes, hvis de gjorde sig skyldig i grov tilsidesættelse af de pligter, som de pågældendes hverv medførte. Tiltale kunne dog alene rejses, hvis det tilsynsråd, der førte tilsyn med kommunen, begærede det. Tilsynsrådet bestod af lokalpolitikere, dog var formanden en regional statslig embedsmand. Reglen blev senere vedtaget ved lov nr. 210 af 16.5 .1984 som $\S 61 \mathrm{c}$ i den kommunale styrelseslov. En væsentlig grund til denne regel var en sag i slutningen af 70'erne. Et aktieselskab havde fået tilladelse til opførelse af et et-etages hotel. Amtet havde givet tilladelse efter planlovgivningen og kommunen byggetilladelse. Selskabet gik under byggeriet konkurs. Efter tvangsauktion gav kommunen køberen en ny byggetilladelse, så hotellet kunne få to etager. Denne tilladelse blev sandsynligvis givet for at gøre hotellet rentabelt og derved give mulighed for færdiggørelsen af byggeriet. Problemet var imidlertid, at kommunen gav denne tilladelse uden at spørge amtet, selv om kommunalbestyrelsesmedlemmerne var klar over, at kun amtet kunne give tilladelse til ændringen til to etager. Bygherren opførte således 
byggeriet uden den fornødne tilladelse, hvilket var strafbart. Anklagemyndigheden ønskede ikke at rejse tiltale mod en privat bygherre, som havde kommunens tilladelse, og valgte i stedet at tiltale kommunen for at være medvirkende til det ulovlige byggeri. Landsretten fandt ikke lovhjemmel for at straffe kommunen som juridisk enhed for medvirken til den privates byggeri. Det fremgår af betænkning nr. 996.1983 s. 108, at denne sag var stærkt medvirkende til, at udvalget gik ind for en regel om straf for kommunalbestyrelsesmedlemmer, som tilsidesatte lovgivningen enten ved at forholde sig passiv til virksomheders strafbare overtrædelser af bl.a. miljølovgivningen, eller som overtrådte loven ved at give ulovlige tilladelser. ${ }^{8}$ Man kan undre sig over, at reglen blev udformet sådan, at den almindelige anklagemyndighed ikke kunne rejse tiltale, medmindre tilsynsrådet med et meget klart flertal af politikere begærede tiltale. På dette tidspunkt var der i Danmark kun et andet område, hvor anklagemyndigheden ikke selv bestemte, om den ville rejse tiltale. Det var tiltale mod ministre, hvor det er folketinget eller regeringen, der rejser tiltalen. Denne regel viser, hvor politiseret spørgsmålet om kommunernes pligt til at overholde miljølovgivningen var.

Forholdet blev ikke bedre af, at en kommune i Vestjylland efter vedtagelsen af straffebestemmelsen i 1984 gav en klart ulovlig byggetilladelse. Der var i kommunen en trikotagefabrik, som på grund af ordretilgang ikke havde plads nok og derfor var nødt til at bygge en ny fabrik. Kommunen ønskede af beskæftigelsesmæssige grunde naturligvis at beholde virksomheden og solgte den en grund til den nye fabrik. Problemet var, at grunden lå uden for byen og altså i landzone. Derfor skulle ikke blot kommunen give en byggetilladelse, men amtet skulle give tilladelse til byggeriet i landzonen. Sagsbehandlingstiden for landzonetilladelsen var for lang til, at fabrikken kunne bruge den til noget. Kommunens byggetilladelse blev derimod udstedt meget hurtigt, og efter aftale med kommunen besluttede fabrikanten sig for at opføre fabrikken, før amtets tilladelse forelå. Amtet reagerede ved at indbringe sagen for domstolene for at få standset byggeriet ved et såkaldt fogedforbud. Dommeren spurgte her fabrikkens repræsentant, om man agtede at standse det klart ulovlige byggeri. Fabrikkens repræsentant svarede nej og oplyste, at man havde en aftale med kommunen om, at eventuelle bøder for det ulovlige byggeri ville blive betalt af kommunen. På grund af sagens åbenbare grovhed undersøgte statsadvokaten den og fandt, at der var grundlag for at tiltale de kommunalbestyrelsesmedlemmer, der havde været med til at lave aftalen med virksomheden, for overtrædelse af den nye bestemmelse i den kommunale styrelseslov $\S 61 \mathrm{c}$. Med formelle begrundelser om, at tilsynsrådet ikke fandt det korrekt at anmode om tiltale, fordi man så burde have gjort det noget før etc., afslog man at give tilladelse til, at der blev rejst tiltale mod politikerne, og statsadvoka- 
ten måtte slutte sagen uden at indbringe den for retten. ${ }^{9}$ Senere er bestemmelsen dog brugt til at straffe kommunalbestyrelsesmedlemmer, der ikke ville politianmelde en større virksomheds klare overtrædelser af miljølovgivningen, fordi de øjensynligt satsede på at få virksomheden ind under det kommunale spildevandsystem og derved give et betydeligt bidrag til dette. ${ }^{10}$ Den anden sag vedrørte kommunalbestyrelsesmedlemmer, som havde stemt for at give en ulovlig byggetilladelse uden at foretage den fornødne behandling efter planlovgivningen. ${ }^{11}$ Reglen findes i dag i § 61, og kravet om tilsynsrådets anmodning om tiltale blev fjernet ved lov nr. 381 af 28.5. 2003.

Når der ovenfor er redegjort forholdsvis udførligt for disse sager mod kommunalbestyrelsesmedlemmer, skyldes det, at sagerne viser det væsentligste problem ved at håndhæve miljølovgivningen i Danmark. Kommunerne, som har ansvaret for håndhævelsen, har i mange tilfælde valgt at prioritere hensynet til beskæftigelsen højere end hensynet til overholdelsen af miljølovgivningen. Dette har kastet et dårligt skær over sagerne, så domstolene med en vis ret har haft svært ved at tage sagerne helt alvorligt. Hvis det er velkendt, at andre kommuner ikke anmelder det, som den tiltalte i dommerens sag aktuelt er tiltalt for, kan det være svært at overbevise dommeren om, at overtrædelsen er meget alvorlig og bør medføre en større bøde. Hvis anklagemyndigheden vil søge at opnå en skærpelse af straffene, kan det derfor være nærliggende at søge oplyst, hvor meget overtræderen har tjent på eller sparet ved overtrædelsen. Det er svært at benægte, at overtrædelser ikke må kunne betale sig, så denne vej viste sig rimelig farbar.

I december 1984 blev et foderstoffirma i Vestre Landsret dømt for fra sit laboratorium i Århus at have udledt kviksølvholdigt spildevand. Spildevandet skulle have været afleveret til Kommunekemi $100 \mathrm{~km}$ fra firmaets laboratorium. Byretten idømte firmaet en bøde på $10.000 \mathrm{kr}$. og begrundede den lille bøde med, »at bøden bør fastsættes i forhold til forbrydelsens grovhed (jf. Straffelovens $\S 80$ ) og ikke i forhold til en mulig opnået besparelse. En besparelse kunne eventuelt sidestilles med udbytte og derved danne grundlag for konfiskation, hvorom der ikke er nedlagt påstand.« Landsretten forhøjede bøden til $100.000 \mathrm{kr}$. og anførte, at den »bør fastsættes under hensyn til lovovertrædelsens grovhed - herunder især det forhold, at det er lagt til grund, at tiltalte i en del af den ovennævnte periode har haft kendskab til, at det udledte spildevand indeholdt kviksølv - og under hensyn til den besparelse, tiltalte havde opnået «. ${ }^{12}$

I 1987 blev en fotovirksomhed i Århus dømt for at have udledt mere sølv end tilladt og for at have undladt at aflevere 300.000 liter fremkalderbade og fikserbade til den kommunale modtagestation. Besparelsen ved den sidste overtrædelse blev oplyst at være $310.000 \mathrm{kr}$. Retten fandt, »at der ved fastsættelsen af den for- 
skyldte bøde skal tages et væsentligt hensyn til den ved lovovertrædelserne opnåede besparelse. Straffen findes herefter passende at kunne fastsættes til en samlet bøde på $350.000 \mathrm{kr}$...., som blev fordelt med $310.000 \mathrm{kr}$. til selskabet og 40.000 kr. til direktøren. ${ }^{13}$

\section{Gyllesagerne}

De første straffesager om forurening, som af rigsadvokaten blev indbragt for Højesteret, vedrørte gylleforurening. Gylle er flydende husdyrgødning, en blanding af gødning og ajle. Forureningen skete ved, at landmændene kørte gyllen ud på marker med en hældning, som medførte, at gyllen havnede i et vandløb. Der var i disse sager ingen fortjeneste, men til gengæld prøvede man at finde et mål for sagernes grovhed. Et samarbejde mellem lokale biologer og anklagere havde medført, at man var begyndt at angive forureningsgraden og dermed til en vis grad grovheden ved at oplyse antallet af personækvivalenter, forkortet PE. En personækvivalent svarer til en persons forurening på et døgn. Man tog altså en vandprøve og undersøgte mængden af organisk forurening i vandet i det øjeblik, hvor prøven blev taget. I de fleste tilfælde var der tale om forholdsvis kortvarige forureninger, men hvis forureningen har stået på $\mathrm{i}$ et år, giver PE-beregningen et fordrejet billede, da denne forurening er mere end 300 gange så alvorlig som en kortvarig forurening med samme målt PE. Langt de fleste gylleforureninger var imidlertid kortvarige, så målemetoden var forsvarlig. På grund af antallet af disse sager var det væsentligt at få en rimelig klar retspraksis for strafudmålingen. Nogle af sagerne vedrørte udledning af ensilage (opbevaret grønfoder). Også denne forurening kan måles ved PE. Højesteret afgjorde den 31.8.1987 disse sager og tilstræbte en betydelig forenkling. ${ }^{14}$ Højesteret indledte sine domme med at konstatere, at der efter lovgivers bemærkninger under behandlingen af miljøbeskyttelsesloven var tale om overtrædelser, som pga. deres store antal gav en betydelig forurening, selv om den enkelte forurening måske ikke var så alvorlig. Højesteret fandt derfor, at bøden burde fastsættes uden hensyn til risikoen for typiske skader eller for sådanne skaders faktiske indtræden, hvorfor retten fastslog, at bøden ved forureninger med under 1000 PE som udgangspunkt skulle fastsættes til $5.000 \mathrm{kr}$. Bøderne blev pålagt ejeren eller den, der drev landbruget for egen regning. Dog gik bøden i den ene sag til en ansat leder, da det var ham, der var tiltalt. I en enkelt sag var forureningen alene målt til $8 \mathrm{PE}$ og uagtsomheden ringe, hvorfor bøden blev $3.000 \mathrm{kr}$. I den sidste sag var en kortvarig forurening angivet til 6916 PE, og bøden blev med henvisning til den dømtes betydelige uagtsomhed ved udledningen fastsat til $10.000 \mathrm{kr}$. Udgangspunktet for gylleforureninger er i dag en bøde på 20.000 kr., jf. Rigsadvokatens Meddelelse 8/2008 pkt. 5.2.4.2 ad § 27. 
En anden overtrædelse ved håndteringen af gylle vedrørte et forbud mod at køre gyllen ud på ubevokset frossen jord. Hvis landmanden havde bygget for lille en beholder til at opbevare gyllen, var han nødt til at køre gyllen fra beholderen ud på markerne, mens disse var frosne. En tiltalt landmand erkendte objektivt overtrædelsen, men hævdede, at han have handlet i lovlig nødret, da skaderne ved ikke at have tømt beholderen ville have været større. Byretten afviste denne undskyldning og idømte ham en bøde på $2.000 \mathrm{kr}$. Landsretten fandt sagen så bagatelagtig, at den burde afgøres med en advarsel. Dette var så klart i strid med intensionerne med reglerne, at sagen blev indbragt for Højesteret, der ikke fandt sagen egnet til afgørelse med advarsel, og derfor idømte en bøde. Under hensyn til, at anklagemyndigheden oprindeligt havde udstedt et bødeforlæg på $2.000 \mathrm{kr}$. og fastholdt denne påstand i byret og landsret, ville Højesteret ikke i den konkrete sag idømme en højere bøde, men fik klart tilkendegivet, at man fandt, at sagen ellers kunne have båret en større bøde. ${ }^{15}$

\section{Dansk kabelskrot og Prom}

To større sager om industriforurening (i vid forstand) blev forelagt Højesteret $\mathrm{i}$ 1990'erne. Begge sager vedrørte virksomheder, som i adskillige år havde givet anledning til betydelig forurening.

Den første sag vedrørte en virksomhed, som samlede og bearbejdede skrot primært i form af gamle ledninger, hvorfra man udvandt bly og kobber mv. ${ }^{16}$ På grund af væsentlige miljøproblemer fik miljømyndighederne virksomheden flyttet til et andet område, hvor der imidlertid også hurtigt opstod problemer med støvforurening af naboernes ejendomme. Tiltalte blev som indehaver og leder af virksomheden tiltalt for en lang række overtrædelser, der formelt var karakteriseret som overtrædelse af vilkårene i virksomhedens miljøgodkendelse og for overtrædelse af en række påbud meddelt af miljømyndighederne. Der var både luftog jordforurening og manglende bortskaffelse af affald, som miljømyndighederne selv måtte fjerne i flere tusinde tons. Byretten idømte en bøde på $200.000 \mathrm{kr}$. med henvisning til gentagne bevidste overtrædelser af vilkårene og nedlagte påbud, til dels med et økonomisk udbytte. Østre Landsret nedsatte bøden til $80.000 \mathrm{kr}$. Nedsættelsen blev begrundet med, at miljømyndighederne havde tilladt virksomhedens placering umiddelbart vest for et boligområde, uanset at de måtte være bekendt med de mulige gener for nærmiljøet, og at myndighederne ved udformningen af godkendelsen kunne have udvist større omhu.

Østre Landsrets dom viser meget klart en af de væsentligste grunde til, at det har været svært at procedere strafudmålingen på overtrædelsernes grovhed. Man må dog erkende, at domstolenes utilfredshed med miljømyndighederne her kom- 
mer usædvanligt klart frem, og rigsadvokaten ankede da også sagen til Højesteret. Højesteret forhøjede bøden til $300.000 \mathrm{kr}$. og lagde vægt på, at tiltalte havde begået en række overtrædelser gennem en længere periode, at han bevidst havde overtrådt vilkår og påbud og opretholdt en ulovlig tilstand, uanset miljømyndighedernes indskærpelser, at der var voldt skade på miljøet, og at overtrædelserne primært havde været motiveret af økonomiske hensyn og da også have givet besparelser for virksomheden.

Til sidst tog Højesteret klart afstand fra de to faktorer, som landsretten havde anført som formildende. At miljømyndighederne havde godkendt en måske ikke hensigtsmæssig placering kunne ikke bevirke en mildere bedømmelse, ligesom det ikke kunne være formildende, at miljømyndighederne i visse henseender måske kunne have udformet godkendelsen mere præcist.

Dommen kan kun læses som et vink med en vognstang til domstolene om, at de skulle koncentrere sig om tiltaltes skyld og ikke søge at finde fejl ved miljømyndighedernes sagsbehandling. Vel at mærke i sager, hvor sagsbehandlingen ikke har efterladt virksomheden i usikkerhed om, hvilke krav den skulle opfylde.

Den anden sag vedrørte en meget omtalt kemi-virksomhed Prom, som i mange år var i miljømyndighedernes søgelys. ${ }^{17}$ Virksomheden havde meget større oplag af kemikalieaffald end tilladt efter virksomhedens godkendelse og havde flere gange undladt at efterkomme påbud om at bortskaffe noget af kemikalieaffaldet. Virksomheden var købt af et anpartsselskab, som fortsatte driften efter det tidligere selskabs miljøgodkendelse, og således overtog det tidligere selskabs rettigheder og pligter. T2 var tiltalt for som ejer af og direktør for selskabet forsætligt at have overtrådt de nævnte vilkår og påbud. Han blev tiltalt sammen med selskabet T1, der var under konkursbehandling. Landsretten, som behandlede sagen $i$ anden instans fandt, at virksomheden ved overtrædelserne havde haft en samlet fortjeneste på 1,6 mio. kr. og idømte selskabet en bøde på $800.000 \mathrm{kr}$. Begrundelsen var bl.a., at landsretten fandt, at forsvaret havde delvis ret i, at miljømyndighederne ikke altid havde håndhævet reglerne konsekvent, men satset på at få virksomheden til at fortsætte $\mathrm{i}$ håbet $\mathrm{om}$, at den ville nedbringe mængden af affald. T 2 fik 40 dages betinget fængsel og en tillægsbøde på $300.000 \mathrm{kr}$. T2 ankede dommen til Højesteret. Højesteret fandt ikke, at nogen del af forholdene var forældede og afviste T2s påstand om, at han var straffri, fordi virksomheden ikke var i stand til at finansiere bortskaffelsen, og derfor skulle frifindes pga. umulighed. I øvrigt fandt Højesteret, at myndighederne havde administreret sagen i overensstemmelse med de almindelige forvaltningsretlige grundsætninger. Højesteret stadfæstede landsrettens strafudmåling og fremhævede, at tiltalte gennem længere tid bevidst havde begået overtrædelserne, og derved ophobet en stor mængde farligt kemika- 
lieaffald med risiko for miljøskade. Desuden blev virksomhedens meget betydelige besparelse tillagt vægt. Højesteret fandt ikke, at myndighedernes håndtering af sagen kunne have givet tiltalte indtryk af, at sagen ikke ville blive anmeldt til politiet og heller ikke de påberåbte økonomiske vanskeligheder kunne betragtes som formildende ved strafudmålingen.

Sagen kan på nogle punkter give anledning til undren. Hvad var meningen med at tiltale et selskab, der var under konkursbehandling? Efter reglerne skal en eventuel bøde i et konkursbo alene betales, hvis alle andre krav indfries, og det er i praksis næppe nogensinde set. Den eneste virkning af en domfældelse er, at staten kommer til at betale forsvaret for selskabet. Anklagemyndigheden begrundede uofficielt tiltalen med, at man var bange for, at selskabet ikke var insolvent, men ville søge at snyde sig fra et strafansvar. En noget fantasifuld forklaring. Det, anklagemyndigheden fik ud af at tiltale selskabet, var, at landsretten fandt, at bøden skulle være $50 \%$ af besparelsen i en sag, hvor der vel at mærke ikke skete konfiskation. Det er et almindeligt princip i Danmark, at en tiltalt ikke som grund til straffrihed eller formildelse kan påberåbe sig økonomisk umulighed, og det gælder for det dømte selskab. Men kan man dømme en ejer og direktør for ikke at have foretaget en bortskaffelse, som selskabet ikke kunne betale? Det vil vel være at pålægge ham en hæftelse for selskabets udgifter, hvilket umiddelbart synes at stride mod reglerne om den begrænsede hæftelse i aktie- og anpartsselskaber. Det havde været rimeligt, at Højesteret havde afgivet en noget mere tilfredsstillende begrundelse for dette. Hvis man ville have dømt T2 til personligt at sørge for bortskaffelsen af affaldet, ville det have krævet en culpa-begrundelse, som vel her måtte gå på, at tiltalte før fortsættelsen af produktionen burde have sikret sig, at der var ressourcer til at bortskaffe affaldet.

\section{Dambrugssagerne}

I 1990'erne blev der ført omkring 100 sager om ulovlig overproduktion i dambrug. Dambrugene lå ved forskellige vandløb i Jylland og var oprettet før miljøbeskyttelseslovens ikrafttræden i 1974 . Ved loven blev indført godkendelseskrav ved oprettelse af nye dambrug, men de eksisterende var lovlige i den form, de havde før lovens ikrafttræden. Når dambrugene blev udvidet, skulle de altså søge godkendelse af hele produktionen. Dambrugerne mente, at godkendelse kun var nødvendig, hvis de øgede forureningen, mens miljømyndighederne hævdede, at der krævedes godkendelse ved en udvidelse, som kunne medføre en øget forurening. Først med Vestre Landsrets dom i Ugeskrift for Retsvæsen 1990 s. 938 fik miljømyndighederne dom for deres fortolkning. Efter lovens ordlyd kunne man altså tvinge dambrugene tilbage til tilstanden pr. 1974. Dette ville fuldstændig 
ødelægge branchen og ruinere ejerne. Langt de fleste af disse havde købt dambrug, der ulovligt var udvidet uden godkendelse, og de havde betalt en pris, der svarede til den samlede produktion. Overordnet blev problemet løst ved et nyt regelsæt specielt for dette område, hvorefter hvert dambrug fik tilladelse til at bruge en vis mængde foder. Og ved beregningen af mængden tog miljømyndighederne i betydelig grad højde for, hvor meget foder det enkelte dambrug havde brugt i de seneste år før tildelingen. Erhvervet var åbenbart blevet vænnet til et frit liv uden håndhævelse, og særdeles mange dambrug fortsatte overtrædelserne ved at bruge mere foder, end de havde fået tilladelse til. De indberettede selv omfanget af forbruget. Så i forhold til skyldsspørgsmålet var sagerne bevismæssigt rimeligt enkle. Problemet var, hvordan man sanktionsmæssigt skulle præsentere sagerne for domstolene. De biologer, der i de jyske amter beskæftigede sig med sagerne, nedsatte en arbejdsgruppe, som lavede en model for udregningen af dambrugernes fortjeneste ved overforbruget. Firkantet sagt havde myndighederne virksomhedernes angivelse af overforbruget. For hver dambrug havde man tal for foderkvotienten for de enkelte år, altså et mål for, hvor meget foder, der skulle til for at give et kg. fisk. På denne måde kunne man opnå et tal for vægten af den samlede overproduktion. Ud fra pristabeller kunne man herefter regne sig frem til salgsværdien af overproduktionen og så fratrække prisen for den ulovligt anvendte foder. Man gav ikke noget fradrag for lønudgifterne ved fodringen, da det ville være at belønne den strafbare aktivitet. For så vidt angik kilopriserne på fisk, blev anvendt standarder frem for de konkrete tal.

Højesteret godkendte i februar 2001 måden disse sager blev ført på og specielt, at beregningerne i et vist omfang blev standardiserede. Det vedrørte primært foderkvotienter, foderpriser, elpriser og salgspriser for de færdige fisk. På et punkt forkastede Højesteret standardiserede beregninger. Den tiltalte dambruger forklarede, at han i en periode ikke havde fodret fiskene for at få dem større, men alene for at holde dem $\mathrm{i}$ live, fordi markedet var så dårligt, at han ved et salg ville have fået en alt for lav pris. Han havde derfor alene fodret for at udskyde salget og således få en højere pris. Højesteret fandt, at man ved beregningen af dambrugerens fortjeneste i disse tilfælde alene måtte regne med den faktiske foderkvotient, og dambrugerens fortjeneste blev således endog meget lille i disse tilfælde. Det forekommer mig ret klart, at Højesteret ved denne fravigelse har set bort fra eller måske snarere overset, at dambrugeren ved sin vedligeholdelsesfodring netop havde skaffet sig en betydelig overpris i forhold til prisen, da fisken var færdig til salg. Det offentliggjorte referat af sagen ${ }^{18}$ tyder ikke på, at anklagemyndigheden har nævnt denne begrundelse for, at standardberegningen nok nærmest ville have været gunstig for denne tiltalte. 
Højesteret konfiskerede den nævnte fortjeneste på $240.000 \mathrm{kr}$. og fastslog, at bøden som udgangspunkt skulle være en fjerdedel af den opnåede fortjeneste. I den konkrete sag burde bøden fastsættes ud fra den fortjeneste, der var udregnet efter standardberegningerne, og bøden blev derfor $95.000 \mathrm{kr}$. Højesteret havde ikke nogen mulighed for at forhøje bøden, da anklagemyndigheden for Højesteret havde påstået stadfæstelse af landsrettens dom. Dette skyldes muligvis, at mange dambrugere i byretterne og landsretterne var idømt bøder på en fjerdedel af fortjenesterne. Højesterets dom blev naturligvis fulgt i de følgende sager.

Højesteret afsagde samme dag dom i en anden dambrugssag. I Ugeskriftet er denne dom udeladt, hvilket tyder på, at Højesteret ikke har ment, at den indeholder noget nyt i forhold til den refererede. Dommen er til gengæld refereret i MAD (Miljøretlige Afgørelser og Domme) 2001 s. 81. Det fremgår heraf, at den dømte ikke var det selskab, der havde drevet dambrugene, men den person, der ledede og ejede selskabet. Selskabet var tilsyneladende under likvidering. Af Rigsadvokatens meddelelse 5/1999 pkt. 2 fremgår, at tiltalen primært skal rettes mod den juridiske person, og at en person i ledelsen kan tiltales, hvis han har handlet forsætligt eller groft uagtsomt, men at dette ikke kan ske, blot fordi selskabet er under konkurs eller lignende.

\section{Udviklingen}

I Arbejdsrapport fra Miljøstyrelsen nr. 771995 Undersøgelse af behandling og sanktionsniveau i miljøstraffesager undersøgte jeg de 84 domme, der i 1993 og 1994 var afsagt vedr. overtrædelse af miljøbeskyttelsesloven. De 5 alvorligste straffe var:

1. 40 dages hæfte og konfiskation af $200.000 \mathrm{kr}$.

2. 40 dages hæfte

3. bøde på $350.000 \mathrm{kr}$.

4. bøde på $300.000 \mathrm{kr}$. og konfiskation af 1,2 mio. kr.

5. bøde på $300.000 \mathrm{kr}$.

I Arbejdsrapport fra Miljøstyrelsen nr. 202005 Undersøgelse af anvendelse af sanktioner m.v. i straffesager på natur-, miljø- og planområdet gennemgik jeg afgørelser fra 2003 og 2004. 133 sager vedrørte overtrædelse af miljøbeskyttelsesloven. 34 af sagerne var afgjort ved dom, 30 i byretterne og 4 i landsretterne. Der var altså betydeligt færre domme end i den første undersøgelse. Top 5 listen var:

1. bøde på $150.000 \mathrm{kr}$. 
2. bøde på $75.000 \mathrm{kr} .+25.000 \mathrm{kr}$.

3. bøde på $75.000 \mathrm{kr}$.

4. bøde på $50.000 \mathrm{kr}$.

5. bøde på $40.000 \mathrm{kr}$.

Ingen af disse sager var afgjort af domstolene, men alle ved, at den eller de tiltalte havde modtaget politiets bødeforlæg. I 1995-top 5 var 1 sag afgjort af Højesteret, 3 af landsretterne og 1 var en byretsdom. Det viser vel ganske klart, at anklagemyndighedens ressourceforbrug i disse sager var faldet markant.

Det svarer ganske til, at mens anklagemyndigheden i 1980erne flere gange årligt afholdt ugelange kurser om håndteringen af miljøstraffesager, har der i de sidste mange år ikke været nogen miljøkurser, bortset fra, at man på det sidste har lavet et éndagskursus. Tilsvarende er de tidligere ugelange kurser for miljømyndighedernes medarbejdere for længst opgivet.

Efter den omtalte 2005-Arbejdsrapport har der været et samarbejde mellem miljøstyrelsen og rigsadvokaten, som har mundet ud i en ændring af miljøbeskyttelsesloven ved indføjelse af den i indledningen nævnte $\S 110$, stk. 5. Formålet med denne indføjelse var at give miljøministeriet mulighed for i bemærkninger til lovforslaget at angive de bødestørrelser, der fremover skulle være udgangspunkt for bødeudmålingen. Det blev her for flere overtrædelser angivet, at udgangspunktet for erhvervslivets overtrædelser, f.eks. af det ovenfor nævnte krav om miljøgodkendelse, skal være en bøde på $50.000 \mathrm{kr}$. Rigsadvokaten har udstedt sin meddelelse nr. 8/2008 om behandling af sager om overtrædelse af miljølovgivningen. Denne indeholder bl.a. nogle retningslinjer for anklagemyndighedens bødepåstande svarende til de nævnte lovbemærkninger. Det er svært ud fra det offentligt tilgængelige materiale at se, om disse retningslinjer følges i praksis og altså har resulteret $i$ en meget betydelig skærpelse af bødestraffen, men mundtlige oplysninger fra anklagere tyder på, at der i denne gruppe af sager er sket en klar skærpelse svarende til lovbemærkningerne. I lovbemærkningerne er også nævnt, at bøderne for overtrædelser af miljøbeskyttelsesloven i sager, hvor der er sket konfiskation, som udgangspunkt bør være en fjerdedel af det konfiskerede beløb. Næppe nogen ville foreslå en så lav bøde for skattesvig, og bemærkningerne viser, at ambitionsniveauet i miljøsager ikke er højt i dag, hverken hos politikerne, anklagerne eller miljømyndighederne. Men noget tyder altså på, at mellemgruppen af sager - de alvorlige, men ikke mest alvorlige - fremover vil blive bedømt væsentligt strengere end hidtil. 


\section{Eftertanke}

Det er tydeligt, at der i de to årtier fra 1980 til 2000 har været brugt betydelige ressourcer på at opnå et tilfredsstillende strafniveau for miljølovsovertrædelser. Strategien har i betydelig grad været at presse niveauet op ved at rette efterforskningen og domstolsbehandlingen mod dokumentation af, at overtrædelserne har givet betydelige gevinster. Inspirationen har i vidt omfang været, at retsvæsnet $\mathrm{i}$ skattestraffesager og i sager om ulovligt fiskeri har straffet overtrædelser hårdt netop med udgangspunkt i de opnåede fortjenester. Thomas Elholm har i 8:13 om bøder og proportionalitet i specialstrafferetten, 2010, givet en udførlig behandling af det generelle problem om strafudmåling i specialstrafferetten, herunder i miljøstraffesager. Elholm argumenterer for, at eventuelle fortjenester bør konfiskeres, og at strafudmålingen bør præges af forholdets grovhed og ikke af konfiskatoriske bøder.

Jeg er ikke overbevist om, at denne strategi ville have medført et mere tilfredsstillende niveau. Problemet har i vidt omfang været, at det har været vanskeligt at overbevise domstolene om alvoren i overtrædelserne. I de sidste 10 år har interessen for området generelt været begrænset, og dette har klart resulteret $i$ en forholdsvis svag håndhævelse. Som nævnt kan 2008-lovændringen muligvis resultere i, at adskillige overtrædelser fremover vil blive vurderet som betydeligt mere alvorlige end før. Er det udtryk for, at strafudmåling efter forholdenes grovhed kan fungere, hvis lovgiver i motiverne giver domstolene meget klare anvisninger? I så fald kan løsningen ligne løsningen på andre områder, f.eks. ved udmålingen af straffen for voldtægt.

\section{Noter}

1. Gorm Toftegaard Nielsen er professor i strafferet og straffeproces ved Aarhus Universitet. Han har tidligere lavet udregninger for miljøstyrelsen om håndhævelsen af miljølovgivningen.

2. §1. Loven skal medvirke til at værne natur og miljø, så samfundsudviklingen kan ske på et bæredygtigt grundlag i respekt for menneskets livsvilkår og for bevarelsen af dyre- og plantelivet.

Stk. 2. Med denne lov tilsigtes særligt

1) at forebygge og bekæmpe forurening af luft, vand, jord og undergrund samt vibrationsog støjulemper,

2) at tilvejebringe hygiejnisk begrundede regler af betydning for miljøet og for mennesker,

3) at begrænse anvendelse og spild af råstoffer og andre ressourcer,

4) at fremme anvendelse af renere teknologi og

5) at fremme genanvendelse og begrænse problemer i forbindelse med affaldshåndtering. 
Henvisningen til $\S 1$ kan virke overflødig, men blev indsat ved lov nr. 173 af 12.3 .2008 for at ministeriet kunne anvise nogle udgangspunkter for strafudmålingen og derved opnå en forhøjelse af bøderne, jf. sidste afsnit i denne artikel.

3. Jf. Niels Waage: Spirituskørsel mv., 5. udg. s. $161 \mathrm{ff}$.

4. Mogens Moe: Miljøret, 7. udg., 2011, s. 418. Sagen er også omtalt i betænkning nr. 981 om håndhævelse af bygge- og miljølovgivningen 1983 s. 222.

5. Ugeskrift for Retsvæsen 1982.202/2 Østre Landsret.

6. Jeg er nærmest inhabil, da jeg selv var anklager i denne sag. Dette gælder imidlertid adskillige af sagerne. Sagen er med i oversigten i betænkning nr. 981.1983 side 222 og refereret s. 224.

7. Optrykt i betænkning nr. 981.1983 s. $221 \mathrm{ff}$.

8. Sagen er refereret i bet. 996.1983 s. 66 f.

9. Da der ikke blev rejst tiltale, er der intet officielt referat af sagen, men den er omtalt af Per Schaumburg-Müller i Juristen 1987 s. 63 ff.

10. Refereret i Orientering fra Miløøstyrelsen, Miljøstraffesager VIII s. 13.

11. Jf. Ugeskrift for Retsvæsen 1993 s. 482 Højesteret. En tredje sag vedr. § 61 c er refereret i Orientering fra Miljøstyrelsen, Miljøstraffesager V s. 22.

12. Ugeskrift for Retsvæsen 1985 s. 950 Vestre Landsret.

13. Sagen er refereret i Orientering fra Miljøstyrelsen, Miljøstraffesager II, 1987, s. 31.

14. Dommene er offentliggjort i Ugeskrift for Retsvæsen 1987 s. $778 \mathrm{ff}$.

15. Ugeskrift for Retsvæsen 1988 s. 904 Højesteret.

16. Ugeskrift for Retsvæsen 1994 s. 267 Højesteret.

17. Ugeskrift for Retsvæsen 2001 s. 2045 Højesteret.

18. Ugeskrift for Retsvæsen 2001 s. 1046.

\section{Litteratur}

Afgørelser af miljøstraffesager blev oprindeligt offentliggjort i Miljøstraffesager I-VIII, der 1987-1996 blev offentliggjort i Orientering fra Miljøstyrelsen. Højesterets afgørelser offentliggøres i Ugeskrift for Retsvæsen (UFR), der også indeholder enkelte landsretsafgørelser. Nogle landsretsafgørelser offentliggøres i Tidsskrift for Kriminalret (TFK). Siden 1996 har Miljøretlige Afgørelser og Domme (MAD) været specialsamlingen for disse afgørelser.

Den bedste oversigt over hele håndhævelsen findes i Mogens Moe: Miljøret, 7. udg. 2010, s. 378-432.

Annette Møller-Sørensen har i Administrativ håndhævelse, 2003, beskrevet og analyseret problemerne ved den primære håndhævelse.

Miljøbeskyttelsesloven af 1991 med kommentarer af Jørgen Bjerring og Gorm Møller, 1998, behandler s. 797-829 strafspørgsmålet.

Vejledning om håndhævelse af miljøbeskyttelsesloven nr. 6/2005 fra Miljøstyrelsen.

Rigsadvokatens Meddelelse (RM) nr. 8/2008 Behandling af sager om overtrædelse af miljølovgivningen. 